\title{
MYD88-DEPENDENT PROTECTIVE IMMUNITY ELICITED BY ADENOVIRUS 5 EXPRESSING THE SURFACE ANTIGEN 1 FROM TOXOPLASMA GONDII IS MEDIATED BY CD8+ T LYMPHOCYTES
}

\author{
Érica A. Mendes ${ }^{1, \#, ~ B r a ́ u l i a ~ C . ~ C a e t a n o ~}{ }^{2, \#}$, Marcus L. O. Penido ${ }^{1}$, Oscar Bruna-Romero ${ }^{3}$, \\ and Ricardo T. Gazzinelli ${ }^{1,2,4,{ }^{*}}$ \\ 1 Departamento de Bioquímica e Imunologia, Instituto de Ciências Biológicas, Universidade \\ Federal de Minas Gerais, 31270-901 Belo Horizonte, MG, Brazil \\ 2 Division of Infectious Disease and Immunology, University of Massachusetts Medical School, \\ 01605 Worcester, MA, USA \\ ${ }^{3}$ Departamento de Microbiologia, Instituto de Ciências Biológicas, Universidade Federal de \\ Minas Gerais, 31270-901 Belo Horizonte, MG, Brazil \\ ${ }^{4}$ Centro de Pesquisas René Rachou, Fundação Oswaldo Cruz, 30190-002 Belo Horizonte, MG, \\ Brazil
}

\begin{abstract}
Toxoplasma gondii is an intracellular parasite widely spread around the world. The Surface Antigens (SAG) 1, 2 and 3 are the main proteins expressed on the surface of $T$. gondii tachyzoites. Replication-defective adenovirus serotype 5 (rAd5) is one of the most potent recombinant viral vectors for eliciting $\mathrm{T}$ cell-mediated immunity in mice and humans. Here we show that vaccination with rAd5 expressing SAG1 (AdSAG1), but neither SAG2 nor SAG3, induces protective immunity in the highly susceptible C57BL/6 mice challenged with $T$. gondii. Furthermore, we evaluated different immunological components involved on viral induced protective immunity. We observed that host protection elicited by AdSAG1 is highly dependent on IL-12, IFN- $\gamma$ and $\mathrm{CD} 8^{+} \mathrm{T}$ lymphocytes. Importantly, the induction of protective immunity (T cell-derived IFN- $\gamma$ ) was also dependent on Myeloid Differentiation Factor 88 (MyD88), and thus, likely to involve Toll-Like receptors. We conclude that protective parasite specific-CD8 ${ }^{+} \mathrm{T}$ cells are elicited by a mechanism that involves MyD88-dependent induction of IL-12.
\end{abstract}

\section{INTRODUCTION}

In the past decades, a variety of strategies have been developed, including the construction of recombinant viruses encoding microbial antigens, so as to achieve more immunogenic

\footnotetext{
(C) 2011 Elsevier Ltd. All rights reserved.

*Corresponding author: Ricardo T. Gazzinelli, Centro de Pesquisas René Rachou, Fundação Oswaldo Cruz, Av. Augusto de Lima 1715, 30190-002 Belo Horizonte, MG, Brazil. Phone no. +55 31 3349-7774; Fax no. +55 31 3349-7835. ritoga@cpqrr.fiocruz.br. \#EAM and BCC equally contributed to this study.

The authors state that the material in question is an original research that has not been published previously and is not submitted to publication elsewhere.

The authors declare no conflict of interest and have nothing to disclose.

Publisher's Disclaimer: This is a PDF file of an unedited manuscript that has been accepted for publication. As a service to our customers we are providing this early version of the manuscript. The manuscript will undergo copyediting, typesetting, and review of the resulting proof before it is published in its final citable form. Please note that during the production process errors may be discovered which could affect the content, and all legal disclaimers that apply to the journal pertain.
} 
vaccines. So far, the replication-defective adenovirus serotype 5 (rAd5) is the most explored vaccine viral vector $[1,2]$. The popularity of adenoviruses as vaccine vectors is due to their ability to elicit strong T cell-mediated immunity [3-7]. In practical terms, immunization of soldiers from U.S. Army with serotypes 4 and 7, efficiently protected against the acute respiratory syndrome - SARS [8]. Importantly, different methods have been used in order to obtain more efficient and safe vectors, capable of abundant expression of heterologous proteins and adequate antigen presentation, necessary to stimulate protective immunity against infectious diseases $[3,9,10]$. A number of adenoviral constructions with sequences of pathogens such as Ebola virus [11], HIV [9, 12], Leishmania chagasi [13], Plasmodium [14, 15], Trypanosoma cruzi [16], Toxoplasma gondii [17], CMV [18] and Rabies virus [19] are highly immunogenic and were successfully used to protect animals against the respective experimental microbial challenge.

However, the mechanism underlying the induction of $\mathrm{T}$ cell-mediated immune responses and protective immunity elicited by adenovirus is poorly understood. Nevertheless, it is well known that infections with adenoviruses typically induce an inflammatory response characterized by an intense cellular infiltrate at the site of viral entrance, with local release of TNF- $\alpha$, IL-1 $\beta$, IL-12, type I IFN and IL-6 [20-22]. Different studies have evaluated the ability of adenoviruses to activate Toll-Like Receptors (TLRs) and nucleotide-binding oligomerization domain-like receptors (NLRs) in vitro and the relevance of these events on viral immunogenicity in vivo [23-26]. For instance, Zhu et al. [25] demonstrated that the induction of type I IFN by adenovirus in plasmacytoid dendritic cells (pDC) is mediated by TLR9. On the other hand, adenovirus was shown to stimulate pro-inflammatory cytokines, both in vitro and in vivo, through the activation of inflammasome via NALP3 [26]. Besides, infection with adenoviruses induces a robust $\mathrm{T}$ cell response, including IFN- $\gamma$ production by $\mathrm{CD}^{+} \mathrm{T}$ lymphocytes, which is partially dependent on TLRs and inflammasome formation [3-7].

Despite of the high rate of infection with $T$. gondii within the human population, the onset of clinical signs of toxoplasmosis is rare in healthy subjects. Nevertheless, $T$. gondii is a main infectious cause of uveitis, and the severe form of the disease appears in immunosuppressed patients and in congenital transmission [27, 28]. In addition, toxoplasmosis is an important veterinary malignancy [29]. Thus, development of a prophylactic vaccine is an important alternative to prevent disease caused by T. gondii infection [30-37].

Genetic studies indicate that different genes are implicated in immune-mediated resistance to $T$. gondii infection [38-40]. Particularly, major MHC alleles are important determinants of resistance to acute infection, as well as controllers of cyst numbers and encephalitis during chronic toxoplasmosis, both in mice and humans [38, 41]. These studies are confirmed by the critical role of $\mathrm{CD} 8^{+} \mathrm{T}$ and $\mathrm{CD} 4^{+} \mathrm{T}$ cells in resistance to primary $T$. gondii infection as well as reactivation of chronic toxoplasmosis [42, 43]. Importantly, studies have also shown that response to immunodominant $\mathrm{CD} 8^{+} \mathrm{T}$ cell epitopes is associated with resistance to $T$. gondii infection [17, 44-46]. In addition, parasite-induced IL-12 is critical to stimulate the production of IFN- $\gamma$ by $\mathrm{CD}^{+}$Th1 cells as well as $\mathrm{CD} 8^{+} \mathrm{T}$ lymphocytes [47, 48]. Thus, an efficient vaccine to prevent toxoplasmosis should elicit an immune response with similar characteristics to the ones described above [49].

We have developed three rAd5 encoding the major Surface Antigens (SAG1, 2 and 3) of $T$. gondii, which were very efficient in inducing both antigen-specific humoral and T cell responses, and protection against challenge with a cystogenic strain of $T$. gondii [17]. In the present study, we investigated the basis of adjuvant activity and mechanism of protection conferred by AdSAG1 vaccination against a lethal challenge with $T$. gondii in the highly susceptible C57BL/6 mice. Our results indicate a critical role of Myeloid Differentiation 
Factor 88 (MyD88), IL-12, IFN- $\gamma$ and CD8 ${ }^{+} \mathrm{T}$ cells in the anti-toxoplasma protective immunity elicited by AdSAG1.

\section{MATERIAL AND METHODS}

Mice

Six week old female Swiss-Webster, C57BL/6, IL-12 ${ }^{-/-}, \beta 2$-microglobulin ${ }^{-/-}$, IFN- $\gamma^{-/-}$, and MyD88 ${ }^{-1-}$ mice were maintained in the animal facility of René Rachou Research Center (Oswaldo Cruz Foundation - FIOCRUZ), Belo Horizonte, Brazil. Animal housing and experimentation were performed according to guidelines of FIOCRUZ Institutional Ethics Committee (Animal protocol P-4/09-2).

\section{Parasites}

ME49, a type II strain of $T$. gondii [50], was maintained by serial passage of cysts in female Swiss-Webster mice. Cysts obtained from mouse brains at 60 days post-infection were used for challenge of vaccinated and control mice. The type I RH strain [51] was maintained by serial passages of tachyzoites in the peritoneal cavity of Swiss-Webster mice and used in the preparation of total tachyzoite lysate (TLA), as previously described by Giraldo and coworkers [52].

\section{Immunization}

Mice received two doses ( $10^{9} \mathrm{PFU}$ each) of adenovirus, 6 weeks apart. Vaccination was performed subcutaneously at the base of the tail, using serotype 5 recombinant adenoviruses diluted in sterile PBS. Groups of immunized mice received recombinant adenoviruses encoding surface antigens SAG1 (AdSAG1), SAG2 (AdSAG2) or SAG3 (AdSAG3) from $T$. gondii [17]. As controls, animals received an adenovirus encoding $\beta$-galactosidase from $E$. coli (AdCTRL). Serum samples obtained before the immunization or 12 days after the last dose of vaccine were used in ELISA and Western-blot assays for detection of anti- $T$. gondii specific antibodies. In some experiments, mice were sacrificed 12-14 days after the last dose of immunization to obtain spleens used in cellular immunological assays. Fourteen days after the last immunization, mice were orally challenged with 10 cysts of ME49 strain and the mortality followed for 50 days.

\section{Peptide synthesis}

MHC I-restricted epitopes were identified in the sequences of SAG1, SAG2 and SAG3 proteins using software SYFPEITHI (www.syfpeithi.de). Nonamers with affinity for molecules $\mathrm{H} 2-\mathrm{L}^{\mathrm{b}}$ and $\mathrm{H} 2-\mathrm{D}^{\mathrm{b}}$ (affinity score $\geq 21$ ) were selected for synthesis. Selected peptides were synthesized by standard $N$ [9-fluorenylmethyloxycarbonyl] on a PSSM8 multispecific peptide synthesizer (Shimadzu, Kyoto, Japan) by solid-phase synthesis. Peptides were purified by HPLC and their identities confirmed by Q-TOF MicroTM equipped with an electrospray ionization source (Micromass, Manchester, UK).

\section{T cell stimulation and cytokine detection assays}

Assays were performed with spleens obtained from 12 to 14 days after the vaccination boost. Spleens were pressed through cell strainers for disruption. Single cell suspensions were then submitted to the red blood cell lyses in $\mathrm{ACK}^{\mathrm{TM}}$ buffer (Sigma, St Louis, USA), washed and suspended in complete medium (RPMI 1640 supplemented with 10\% fetal bovine serum, $25 \mathrm{mM}$ HEPES, $1 \mathrm{mM}$ sodium pyruvate and $1 \mathrm{mM}$ L-glutamine). Total spleen cells were platted in 24 -well plates $\left(5 \times 10^{6}\right.$ cells per well) in complete medium in the absence or presence of synthetic peptides $(50 \mu \mathrm{M})$ or TLA $(10 \mu \mathrm{g} / \mathrm{ml})$ and incubated at $37^{\circ}$ 
$\mathrm{C}$ and $5 \% \mathrm{CO}_{2}$ for 24-48 hours. The concentration of IFN- $\gamma$, IL-4 and IL-10 in cell-free

supernatants was estimated by ELISA assay (DuoSet ${ }^{\mathrm{TM}}, \mathrm{R} \& \mathrm{D}$ Systems, Minneapolis, USA).

\section{Enzyme-linked immunospot assays}

Nitrocellulose-bottom 96-well plates (Millipore) were coated overnight with $10 \mu \mathrm{g} / \mathrm{ml}$ of an anti-mouse IFN- $\gamma$ monoclonal antibody (clone R4-6A2, BD Biosciences, San Jose, USA) and blocked for 2 hours at $37^{\circ} \mathrm{C}$ with RPMI medium containing $10 \%$ fetal bovine serum. Spleens were collected between 12 and 14 days after the last dose of adenovirus and processed as described above. Cells were plated $\left(10^{6}\right.$ cells per well) in plain complete medium or in the presence of synthetic peptides $(50 \mu \mathrm{M})$ or TLA $(10 \mu \mathrm{g} / \mathrm{ml})$. Cells were stimulated for 24 hours at $37^{\circ} \mathrm{C}$ and $5 \% \mathrm{CO}_{2}$. Cells were discarded and plates were washed thoroughly in PBS. The plates were then incubated with a biotinylated anti-mouse IFN- $\gamma$ antibody (clone XMG1.2, BD Biosciences), followed by peroxidase-labeled streptavidin (BD Biosciences). Spots were developed with peroxidase substrate containing $1 \mathrm{mg} / \mathrm{ml}$ of 3,3-diaminobenzidine tetrahydrochloride and $1 \mu \mathrm{l} / \mathrm{ml}$ of $30 \%$ hydrogen peroxide in $50 \mathrm{mM}$ Tris buffer $(\mathrm{pH}=7.5)$. Reactions were stopped under running water. Spots were counted in ImmunoSpot CTL (Cellular Technology Ltd., Shaker Heights, USA)

\section{ELISA and Western blot}

Detection of anti-SAG specific antibodies by ELISA was performed in microtiter plates coated overnight with TLA $(5 \mu \mathrm{g} / \mathrm{ml}$ in carbonate buffer $\mathrm{pH}=9.5)$ and blocked for 2 hours at $37^{\circ} \mathrm{C}$ with PBS supplemented with $10 \%$ fetal bovine serum. Sera from vaccinated and control mice were diluted 1:50 in PBS and added to plates for 2 hours at $37^{\circ} \mathrm{C}$. Plates were then incubated with peroxidase-conjugated anti-mouse total $\mathrm{IgG}$ for 45 minutes at $37^{\circ} \mathrm{C}$. Reactions were developed with substrate containing tetramethylbenzidine (TMB, Sigma) for 30 minutes at room temperature. Reactions were stopped with $2 \mathrm{~N} \mathrm{H}_{2} \mathrm{SO}_{4}$ and read at 450 $\mathrm{nm}$. For detection of anti-SAG antibodies by Western blot, TLA samples (5-10 $\mu \mathrm{g}$ per sample) were run in $12 \%$ SDS-PAGE gels under denaturing conditions and transferred onto nitrocellulose membranes. Strips were cut from membranes and blocked overnight at $4^{\circ} \mathrm{C}$ in PBS containing 5\% skim milk. Strips were then incubated with serum from either vaccinated or control mice diluted 1:1000 in the blocking buffer, for one hour. After wash, strips were incubated with peroxidase-conjugated goat anti-mouse IgG (Sigma) diluted 1:3000, for one additional hour. Reactions were detected with chemiluminescence reagent (ECL Plus Western Blotting Detection Reagent ${ }^{\mathrm{TM}}$, Amersham Biosciences, Piscataway, USA) and exposure of membranes to X-ray films (Hyperfilm ${ }^{\mathrm{TM}}$, Amersham Biosciences).

\section{Statistical analysis}

The difference in cumulative mortality of experimental groups was analyzed using Log-rank (Mantel-Cox) test. The numbers of cysts in the brain were compared using t test of MannWhitney. The comparison of IgG levels in the sera (ELISA) was performed with $t$ test, whereas the number of specific $\mathrm{CD} 8^{+} \mathrm{T}$ cells (ELISPOT) and the amount of cytokines secreted by splenocytes (ELISA) were compared using ANOVA test with Bonferroni's posttest for comparing all pairs of groups. All tests were performed in GraphPad Prism 5.0 (GraphPad Softwares Inc., La Jolla, USA), and differences were considered statistically significant when $p<0.05$. 


\section{RESULTS}

\section{Humoral and cellular immune responses after vaccination with recombinant adenoviruses encoding SAG antigens from $T$. gondii}

Serum samples were obtained from C57BL/6 mice two weeks after the last dose of rAd5 encoding one of the surface antigens SAG1 (AdSAG1), SAG2 (AdSAG2) or SAG3 (AdSAG3) from $T$. gondii or $\beta$-galactosidase from E. coli (AdCTRL), as an unrelated antigen. All samples were individually tested by Western blot for their reactivity with tachyzoite lysate antigens (TLA). Figure 1A shows that antibodies in sera from AdSAGvaccinated mice specifically recognize the different SAG proteins, which indicates that all three rAd5 were capable to express in vivo the recombinant antigens. Apparent molecular weight of proteins recognized by antibodies in sera from vaccinated mice were consistent with those expected for each protein, i.e., SAG1,30Kd; SAG2, 22Kd; and SAG3, 43Kd.

We also analyzed the cellular immune responses induced by vaccination of C57BL/6 mice with rAd5 by measuring the levels of cytokines produced by spleen cells. The splenocytes were obtained two weeks after the boost and stimulated in vitro with TLA for 24 or 48 hours. The levels of IFN- $\gamma$, IL-4 and IL-10 were measured in tissue culture supernatants by ELISA. Significant levels of IFN- $\gamma$ were produced by splenocytes from mice vaccinated with either AdSAG1 or AdSAG2 (figure 1B), whereas no significant production of IL-4 or IL-10 was detected.

To further explore the development of cellular immune responses after immunization, we measured the frequency of SAG-specific IFN- $\gamma$ producing $\mathrm{CD} 8^{+} \mathrm{T}$ cells. For that purpose, we employed an ELISPOT assay in which total spleen cells were stimulated for 24 hours with SAG-derived synthetic peptides encoding MHC I-restricted epitopes. An in silico screen of SAG1, SAG2 and SAG3 was performed to identify potential ligands of $\mathrm{H} 2$ molecules from haplotype "b", which is expressed by C57BL/6 mice. Our analysis indicated the presence of one candidate peptide in SAG1 and two candidates in SAG3. All peptides had high affinity for $\mathrm{H} 2-\mathrm{D}^{\mathrm{b}}$ or $\mathrm{H} 2-\mathrm{L}^{\mathrm{b}}$ (figure $1 \mathrm{C}$ ). The same method failed to identify $\mathrm{H} 2-$ binding epitopes in SAG2 sequence. Figure 1C shows the results of the ELISPOT assay. The peptide TPTENFTL (SP0534) from SAG1 is recognized specifically by CD8 ${ }^{+} \mathrm{T}$ lymphocytes of AdSAG1-immunized C57BL/6 mice and induces IFN- $\gamma$ secretion by those cells. Stimulation with two different SAG3-derived peptides had no effect on in vitro detection of SAG3-specific $\mathrm{CD}^{+} \mathrm{T}$ cells from spleen culture from mice vaccinated with AdSAG3.

\section{Protection induced by vaccination with recombinant adenoviruses encoding SAG proteins from T. gondii}

To determine if rAd5 encoding $S A G$ genes were capable to elicit protective immunity, the highly susceptible C57BL/6 mice were vaccinated and challenged per-orally with 10 cysts of ME49 strain of $T$. gondii. Groups of mice immunized that received two doses of AdSAG1 presented significantly higher survival (figure $2 \mathrm{~A}$ ) than those vaccinated with AdSAG2 or AdSAG3 $(p<0.01)$. We also evaluated the number of cysts in the brain of the animals that survived the challenge with $T$. gondii. Mice vaccinated with AdSAG1 had lower number of cysts when compared to groups of animals vaccinated with either AdSAG2 or AdSAG3 (figure 2B). In two experiments, only one animal from AdCTRL group survived until 50 days after challenge, and this mouse had a high number of cysts in its brain (approximately 1000 cysts). Since only vaccination with AdSAG1 was capable of inducing strong antigen specific IFN- $\gamma$ responses and protection against $T$. gondii infection, we used this virus in the subsequent experiments designed to define the mechanism involved on induction of protective immunity. 


\section{CD8 ${ }^{+} \mathrm{T}$ cells and IFN- $\mathrm{Y}$ are key elements on effector functions and protective immunity elicited by vaccination with AdSAG1}

$\mathrm{CD}^{+} \mathrm{T}$ cells are considered important mediators of protection against $T$. gondii [49]. These cells contribute to the production of IFN- $\gamma$, which is essential for resistance against tachyzoites during the acute phase of infection [53-55]. Therefore, we explored the relevance of $\mathrm{CD}^{+} \mathrm{T}$ cells and IFN- $\gamma$ production in our immunization protocol. For this purpose, we vaccinated IFN- $\gamma^{-1-}$ as well as $\beta 2-$ microglobulin ${ }^{-1-}$ (deficient in $\mathrm{CD}^{+} \mathrm{T}$ cells) mice, alongside with wild type (WT) animals. All mouse lineages were vaccinated with AdSAG1 according to the protocol used in previous experiments. Subsequently, the animals were challenged with a per-oral dose of ME49 strain, and survival compared between WT and knockout lineages.

Vaccination of WT mice with AdSAG1 lead to a significant increase in survival. All vaccinated IFN- $\gamma^{-1-}$ mice succumbed to acute infection around two weeks after challenge. The totality of $\beta 2$-microglobulin ${ }^{-1}$ animals, including those vaccinated with AdSAG1, also died after challenge with mortality occurring from 2 to 6 weeks post-infection (figure 3A). Consistently, splenocytes from $\beta 2$-microglobulin ${ }^{-1-}$ mice stimulated with SAG1-derived peptide did not secret IFN- $\gamma$ (figure 3B), showing that the selected peptide was indeed specific for $\mathrm{CD} 8^{+} \mathrm{T}$ cells, and further indicating that this $\mathrm{T}$ cell subset is an important source of IFN- $\gamma$ in AdSAG1 vaccinated mice.

\section{Induction of protective immunity by vaccination with AdSAG1 is dependent on functional MyD88 and IL-12 secretion}

The MyD88 is an adaptor protein that is critical for cell signaling by all TLRs, except TLR3 [56]. Thus, MyD88 is central to activation of innate immune responses, and the mechanisms that mediate the adjuvant properties of different vaccine formulations, including viral vectors. Here we investigated whether MyD88 also plays a role in the development of antigen specific $\mathrm{T}$ cell as well as humoral immune responses and protective immunity elicited by AdSAG1. Indeed, the protection observed in C57BL/6 mice vaccinated with AdSAG1 was abrogated in MyD88 ${ }^{-1-}$ mice. All the MyD88 deficient mice succumbed to infection around 21 days after challenge (figure 4A). Consistently, the IFN- $\gamma$ response of spleen cells to either TLA or peptide-specific $\mathrm{CD}^{+} \mathrm{T}$ cells was severely impaired in

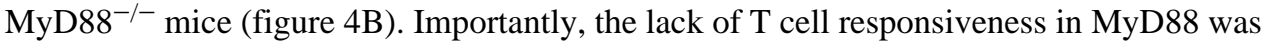
not due to a failure in the immunization protocol, since the levels of anti-SAG1 antibodies in

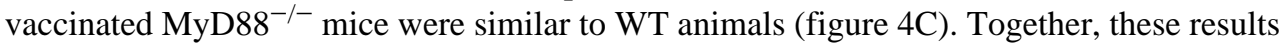
that TLRs are central for induction of antigen-specific $\mathrm{T}$ cell mediated immunity elicited by rAd5.

Secretion of IL-12 by innate immune cells is a key element on induction of IFN- $\gamma$ production by $\mathrm{T}$ cells, including $\mathrm{CD} 8^{+} \mathrm{T}$ lymphocytes, and development of protective immunity to a variety of intracellular pathogens, including $T$. gondii $[47,48]$. As IL-12 is a main output of TLR activation by microbial components, we were also interested in evaluating the role of IL-12 in the protection conferred by immunization with AdSAG1. As observed in previous experiments, around 70\% of AdSAG1-vaccinated C57BL/6 mice survived the challenge with ME49 (figure 5A). However, the counterpart group of animals deficient in IL-12 died within 14 days after challenge. As observed with MyD88 ${ }^{-/-}$, the IFN- $\gamma$ production in response to both TLA and peptide SP0534 was severely impaired in splenocytes from IL-12 ${ }^{-/-}$mice vaccinated with AdSAG1. Taken together, our results indicate that TLR-induced IL-12 is critical for the development of IFN- $\gamma$-producing T cells and immune-mediated resistance to T. gondii infection induced by AdSAG1. 


\section{DISCUSSION}

Various experimental models and vaccine formulations have been used in attempts to generate an efficient and safe protocol for immunization against toxoplasmosis. Some studies indicate that protective immunity is achievable by inoculation of animals with plasmid vectors encoding parasite genes, as well as purified or recombinant proteins derived from T. gondii [30-37]. Although many of these vaccination protocols were able to generate partial protection against experimental toxoplasmosis, they display relatively weak immunogenicity, particularly for eliciting responses of $\mathrm{CD}^{+} \mathrm{T}$ cells, which are critical for protective immunity against $T$. gondii infection [55, 57]. In this regard, rAd5 represent an interesting alternative when compared to other formulations of recombinant vaccines. They are extremely efficient in inducing high levels of expression of recombinant antigen in host cells in vivo [5], including professional antigen presenting cells such as dendritic cells, Kupffer cells and macrophages [7, 58]. In addition, viral particles are endowed with different components (e.g. proteins, glycoproteins and nucleic acids) that interact with innate immune receptors and trigger a plethora of inflammatory mediators that exert adjuvant effects on the immunological response to the ectopically expressed proteins $[59,60]$. Thus far, rAd5 seems to be the best characterized viral vector on its ability to stimulated strong $\mathrm{CD}^{+} \mathrm{T}$ as well as $\mathrm{CD} 8^{+} \mathrm{T}$ cell responses [3-7].

Having these immunological properties in mind, we have chosen the rAd5 as a vaccine vector for expression of three surface antigens (SAG1, SAG2 and SAG3) of T. gondii and development of a prophylactic vaccine for toxoplasmosis. In a previous study from our group, the immunization with rAd5 expressing SAG1, SAG2 or SAG3 resulted in significant protection in $\mathrm{BALB} / \mathrm{c}$ mice challenged with the $\mathrm{PBr}$ strain of $T$. gondii [17]. Here, we tested the three different viruses in the highly susceptible C57BL/6 mice. We verified that only AdSAG1 induced a strong $\mathrm{T}$ cell response and protection against challenge with $T$. gondii parasites. The observation that SAG1 is an efficient immunogen is consistent with previously published studies. More precisely, different studies demonstrate that various formulations containing SAG1 as antigen are able to partially protect mice against challenge with different strains of $T$. gondii [30-32]. Moreover, vaccines that associate SAG1 with other antigens from $T$. gondii confer protection even to challenge with the highly virulent RH strain [36, 37].

We observed a direct correlation of IFN- $\gamma$ levels secreted by $\mathrm{CD} 4^{+} \mathrm{T}$ as well as $\mathrm{CD} 8^{+} \mathrm{T}$ and development of protective immunity. Whereas, mice vaccinated with AdSAG1 produced high levels of IFN- $\gamma$ in response to TLA (mediated mainly by CD4 ${ }^{+} \mathrm{T}$ cells) and a CD8 ${ }^{+} \mathrm{T}$ cell epitope, on the other hand, the animals that received AdSAG2 or AdSAG3 showed a weaker response. The expression and delivery to immune system of SAG2 and SAG3 in vivo by the rAd5 was successful, as indicated by the presence of anti-SAG2 or -SAG3 specific antibodies in vaccinated animals. Thus, the lower IFN- $\gamma$ response in mice vaccinated with AdSAG2 and AdSAG3 is probably related to the fact that SAG2 and SAG3 antigens are weak stimulators of $\mathrm{T}$ lymphocytes, in the context of $\mathrm{H} 2$ molecules from haplotype "b" displayed by C57BL/6. Nevertheless, the results obtained with AdSAG1 are consistent with the various studies indicating that rAd5 is a potent inducer of both CD4 ${ }^{+} \mathrm{T}$ as well as $\mathrm{CD}^{+} \mathrm{T}$ lymphocytes [3-7], which are main sources of IFN- $\gamma$ and host resistance to toxoplasmosis [53-55].

We next investigated the immunological mechanisms responsible for the protection observed in mice vaccinated with AdSAG1. We evaluated the involvement of CD8 ${ }^{+} \mathrm{T}$ lymphocytes as well as IFN- $\gamma$, two critical elements on effector mechanisms of immunemediated resistance to $T$. gondii infection. Consistent with previous reports on the essential role of IFN- $\gamma$ in controlling toxoplasmosis $[47,61]$, IFN- $\gamma^{-l-}$ mice vaccinated with AdSAG1 
were still highly susceptible to ME49 strain, with $100 \%$ lethality in the first two weeks after infection. The $\beta 2$ microglobulin ${ }^{-1-}$ mice were not able to mount a full IFN- $\gamma$ response even when vaccinated with AdSAG1, and succumbed to infection, in this case, in a later stage of disease, between 35-40 days post-infection.

The primary defect of the $\beta_{2}$ microglobulin ${ }^{-/-}$mice is the lack of class I MHC molecules, and therefore, they do not have $\mathrm{CD} 8^{+} \mathrm{T}$ cells. However, $\mathrm{CD} 4^{+} \mathrm{T}$ cells are still functional in these mice. Thus, we observed only a partial ablation of IFN- $\gamma$ production in vaccinated $\beta 2$ microglobulin ${ }^{-1-}$ mice. These observations indicate that $\mathrm{CD} 8^{+} \mathrm{T}$ cells are an important source of IFN- $\gamma$, however, an additional source, most likely $\mathrm{CD}^{+}{ }^{+} \mathrm{T}$ cells and NK cells, are necessary to explain the difference in susceptibility, when comparing vaccinated IFN- $\gamma^{-/-}$ and $\beta 2$-microglobulin ${ }^{-1-}$ mice. Nevertheless, as efficient as $\mathrm{CD} 4^{+} \mathrm{T}$ cells may be in producing IFN- $\gamma$ in response to $T$. gondii antigens, they were not sufficient, in absence of $\mathrm{CD} 8^{+} \mathrm{T}$ cells, to fully protect vaccinated mice.

The observation that $\mathrm{CD} 8^{+} \mathrm{T}$ cells control the development of chronic disease is consistent with other studies using post-vaccination depletion of $\mathrm{CD} 8^{+} \mathrm{T}$ cells [62]. Furthermore, transfer of $\mathrm{CD}^{+} \mathrm{T}$ cells from immunized or infected mice protects animals from cyst formation and mortality during chronic toxoplasmosis [54, 63]. In contrast, the IFN- $\gamma$, MyD88, or IL-12 deficient mice, vaccinated with AdSAG1 or control rAd5, all died by day 20 post-infection. Thus, together, our results indicate that MyD88, IL-12 and IFN- $\gamma$ have a primary role during the early stage of infection (in the site of parasite entry at the mucosa and other peripheral organs), whereas $\mathrm{CD} 8^{+} \mathrm{T}$ cells would be critical for controlling parasite replication and cyst formation in the central nervous system (CNS). Although we do not discard the possibility that $\mathrm{T}$ cells are also restraining parasite replication in other organs, such as lungs or even the intestine, it seems that the CNS is the main site where T lymphocytes control cyst formation and reactivation during chronic infection with $T$. gondii [64]. Consistently, Suzuki and colleagues (2010) demonstrated that both $\mathrm{CD}^{+} \mathrm{T}$ and $\mathrm{CD} 8^{+}$ $\mathrm{T}$ cells can infiltrate areas around the cysts, but only in presence of $\mathrm{CD} 8^{+} \mathrm{T}$ there is effective elimination of cysts [54].

A second major question addressed in our studies was the critical role of innate immunity in induction of $\mathrm{T}$ cell responses and protective immunity elicited by AdSAG1. Different studies have indicated a primary role of MyD88/TLRs [24, 25] as well as inflammasome/ NLRs [26] in triggering innate immunity and pro-inflammatory cytokines, as consequence of the intrinsic adjuvant activity of rAd5 [59,60]. Importantly, a recent study have indicated a redundant role of TLRs and NLRs on immunogenicity and development of acquired T cell-mediated immunity in mice vaccinated with rAd5 [7]. Here, we tested the involvement of TLR signaling in the adjuvant properties of rAd5, by vaccinating and challenging animals devoid of MyD88. We observed that the protective IFN $-\gamma$ response was abrogated in

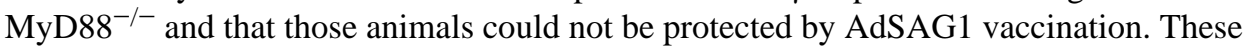
findings are in contrast with studies indicating that $\mathrm{T}$ cell-mediated immunity and protection induced by a live attenuated strain of $T$. gondii occurs independent of MyD88/TLR function [65]. Although the production of IFN- $\gamma$ in MyD88 ${ }^{-/-}$was severely impaired, these mice were capable to produce high levels of specific IgG. This was also observed in another study, which indicated that MyD88 signaling is not essential for antibodies production, but is indispensable for protection against Streptococcus pneumonia infection following oral vaccination with attenuated Salmonella, as well as in our vaccination model [66, 67]. Therefore, the results presented here are consistent with the hypothesis that TLRs/MyD88 play an important role in the adjuvant activity, immunogenicity and development of protective immunity induced by rAd5 [7, 24]. 
Finally, IL-12 has been shown to elicit the development of T cell-mediated immunity induced by immunological adjuvants, including various TLR agonists, e.g. LPS and unmethylated CpG-containing oligonucleotides [68]. Furthermore, IL-12 appears to be critical to the optimal IFN- $\gamma$ response by $\mathrm{CD} 4^{+} \mathrm{T}$ and $\mathrm{CD} 8^{+} \mathrm{T}$ lymphocytes during different microbial infections, including experimental toxoplasmosis [47, 49, 55]. Indeed, by inducing both T cell-dependent and independent IFN- $\gamma$, IL-12 has been defined as a critical factor in host resistance to infection with $T$. gondii [47]. Our experiments show that vaccinated IL- $12^{-/-}$mice had an impaired IFN- $\gamma$ response and were highly susceptible to challenge with $T$. gondii.

In summary, our results show that protective immunity observed in mice vaccinated with AdSAG1 is dependent on activation of MyD88 and IL-12 production. In turn, MyD88dependent production of IL-12 will induce both antigen-specific $\mathrm{CD} 4^{+} \mathrm{T}$ and $\mathrm{CD} 8^{+} \mathrm{T}$ cells, which are an important source of IFN- $\gamma$, leading to control of parasitism and survival in AdSAG1 vaccinated mice challenged with $T$. gondii.

\section{Acknowledgments}

This study was supported by the National Institute of Health (RO1 AI071319-04 and U01 AI07787-01); the National Institute of Science and Technology for Vaccines/Conselho Nacional de Desenvolvimento Científico e Tecnológico (CNPq) and the Programa de Desenvolvimento de Tecnologia e Insumos em Saúde from Fundação Oswaldo Cruz (PDTIS-FIOCRUZ). EAM is a PhD student supported by Capes; BCC is a post-doctoral fellow, and RTG a research fellow supported by CNPq.

\section{References}

1. Hartman ZC, Appledorn DM, Amalfitano A. Adenovirus vector induced innate immune responses: impact upon efficacy and toxicity in gene therapy and vaccine applications. Virus Res. 2008; 132(1-2):1-14. [PubMed: 18036698]

2. Draper SJ, Heeney JL. Viruses as vaccine vectors for infectious diseases and cancer. Nat Rev Microbiol. 8(1):62-73. [PubMed: 19966816]

3. Gao G, Wang Q, Dai Z, Calcedo R, Sun X, Li G, et al. Adenovirus-based vaccines generate cytotoxic T lymphocytes to epitopes of NS1 from dengue virus that are present in all major serotypes. Hum Gene Ther. 2008; 19(9):927-36. [PubMed: 18788905]

4. Bayer W, Tenbusch M, Lietz R, Johrden L, Schimmer S, Uberla K, et al. Vaccination with an adenoviral vector that encodes and displays a retroviral antigen induces improved neutralizing antibody and CD4+ T-cell responses and confers enhanced protection. J Virol. 2010; 84(4):196776. [PubMed: 20007267]

5. Holst PJ, Orskov C, Thomsen AR, Christensen JP. Quality of the transgene-specific CD8+ T cell response induced by adenoviral vector immunization is critically influenced by virus dose and route of vaccination. J Immunol. 2010; 184(8):4431-9. [PubMed: 20212099]

6. Makedonas G, Hutnick N, Haney D, Amick AC, Gardner J, Cosma G, et al. Perforin and IL-2 upregulation define qualitative differences among highly functional virus-specific human CD8 T cells. PLoS Pathog. 2010; 6(3):e1000798. [PubMed: 20221423]

7. Lindsay RW, Darrah PA, Quinn KM, Wille-Reece U, Mattei LM, Iwasaki A, et al. CD8+ T Cell Responses following Replication-Defective Adenovirus Serotype 5 Immunization Are Dependent on CD11c+ Dendritic Cells but Show Redundancy in Their Requirement of TLR and NucleotideBinding Oligomerization Domain-Like Receptor Signaling. J Immunol. 2010; 185(3):1513-21. [PubMed: 20610651]

8. Howell MR, Nang RN, Gaydos CA, Gaydos JC. Prevention of adenoviral acute respiratory disease in Army recruits: cost-effectiveness of a military vaccination policy. Am J Prev Med. 1998; 14(3): 168-75. [PubMed: 9569216]

9. Hidajat R, Kuate S, Venzon D, Kalyanaraman V, Kalisz I, Treece J, et al. Construction and immunogenicity of replication-competent adenovirus 5 host range mutant recombinants expressing HIV-1 gp160 of SF162 and TV1 strains. Vaccine. 2010; 28(23):3963-71. [PubMed: 20382241] 
10. Thacker EE, Nakayama M, Smith BF, Bird RC, Muminova Z, Strong TV, et al. A genetically engineered adenovirus vector targeted to CD40 mediates transduction of canine dendritic cells and promotes antigen-specific immune responses in vivo. Vaccine. 2009; 27(50):7116-24. [PubMed: 19786146]

11. Sullivan NJ, Geisbert TW, Geisbert JB, Xu L, Yang ZY, Roederer M, et al. Accelerated vaccination for Ebola virus haemorrhagic fever in non-human primates. Nature. 2003; 424(6949): 681-4. [PubMed: 12904795]

12. Asmuth DM, Brown EL, DiNubile MJ, Sun X, del Rio C, Harro C, et al. Comparative cellmediated immunogenicity of DNA/DNA, DNA/adenovirus type 5 (Ad5), or Ad5/Ad5 HIV-1 clade B gag vaccine prime-boost regimens. J Infect Dis. 2010; 201(1):132-41. [PubMed: 19929694]

13. Resende DM, Caetano BC, Dutra MS, Penido ML, Abrantes CF, Verly RM, et al. Epitope mapping and protective immunity elicited by adenovirus expressing the Leishmania amastigote specific A2 antigen: correlation with IFN-gamma and cytolytic activity by CD8+ T cells. Vaccine. 2008; 26(35):4585-93. [PubMed: 18588933]

14. Bruna-Romero O, Gonzalez-Aseguinolaza G, Hafalla JC, Tsuji M, Nussenzweig RS. Complete, long-lasting protection against malaria of mice primed and boosted with two distinct viral vectors expressing the same plasmodial antigen. Proc Natl Acad Sci U S A. 2001; 98(20):11491-6. [PubMed: 11553779]

15. Rodriguez A, Mintardjo R, Tax D, Gillissen G, Custers J, Pau MG, et al. Evaluation of a primeboost vaccine schedule with distinct adenovirus vectors against malaria in rhesus monkeys. Vaccine. 2009; 27(44):6226-33. [PubMed: 19686691]

16. Machado AV, Cardoso JE, Claser C, Rodrigues MM, Gazzinelli RT, Bruna-Romero O. Long-term protective immunity induced against Trypanosoma cruzi infection after vaccination with recombinant adenoviruses encoding amastigote surface protein- 2 and trans-sialidase. Hum Gene Ther. 2006; 17(9):898-908. [PubMed: 16972758]

17. Caetano BC, Bruna-Romero O, Fux B, Mendes EA, Penido ML, Gazzinelli RT. Vaccination with replication-deficient recombinant adenoviruses encoding the main surface antigens of toxoplasma gondii induces immune response and protection against infection in mice. Hum Gene Ther. 2006; 17(4):415-26. [PubMed: 16610929]

18. de Andrade BP, Gazzinelli RT, Del Val M, Bruna-Romero O. Protective immunization against murine cytomegalovirus infection using adenoviruses and poxviruses expressing hepatitis $\mathrm{B}$ virus chimeras. Int Microbiol. 2007; 10(4):261-9. [PubMed: 18228223]

19. Henderson H, Jackson F, Bean K, Panasuk B, Niezgoda M, Slate D, et al. Oral immunization of raccoons and skunks with a canine adenovirus recombinant rabies vaccine. Vaccine. 2009; 27(51): 7194-7. [PubMed: 19925952]

20. Ginsberg HS, Horswood RL, Chanock RM, Prince GA. Role of early genes in pathogenesis of adenovirus pneumonia. Proc Natl Acad Sci U S A. 1990; 87(16):6191-5. [PubMed: 2166948]

21. Di Paolo NC, Miao EA, Iwakura Y, Murali-Krishna K, Aderem A, Flavell RA, et al. Virus binding to a plasma membrane receptor triggers interleukin-1 alpha-mediated proinflammatory macrophage response in vivo. Immunity. 2009; 31(1):110-21. [PubMed: 19576795]

22. Zaiss AK, Vilaysane A, Cotter MJ, Clark SA, Meijndert HC, Colarusso P, et al. Antiviral antibodies target adenovirus to phagolysosomes and amplify the innate immune response. $\mathrm{J}$ Immunol. 2009; 182(11):7058-68. [PubMed: 19454703]

23. Appledorn DM, Patial S, McBride A, Godbehere S, Van Rooijen N, Parameswaran N, et al. Adenovirus vector-induced innate inflammatory mediators, MAPK signaling, as well as adaptive immune responses are dependent upon both TLR2 and TLR9 in vivo. J Immunol. 2008; 181(3): 2134-44. [PubMed: 18641352]

24. Hartman ZC, Kiang A, Everett RS, Serra D, Yang XY, Clay TM, et al. Adenovirus infection triggers a rapid, MyD88-regulated transcriptome response critical to acute-phase and adaptive immune responses in vivo. J Virol. 2007; 81(4):1796-812. [PubMed: 17121790]

25. Zhu J, Huang X, Yang Y. Innate immune response to adenoviral vectors is mediated by both Tolllike receptor-dependent and -independent pathways. J Virol. 2007; 81(7):3170-80. [PubMed: 17229689] 
26. Muruve DA, Petrilli V, Zaiss AK, White LR, Clark SA, Ross PJ, et al. The inflammasome recognizes cytosolic microbial and host DNA and triggers an innate immune response. Nature. 2008; 452(7183):103-7. [PubMed: 18288107]

27. Weiss LM, Dubey JP. Toxoplasmosis: A history of clinical observations. Int J Parasitol. 2009; 39(8):895-901. [PubMed: 19217908]

28. Elmore SA, Jones JL, Conrad PA, Patton S, Lindsay DS, Dubey JP. Toxoplasma gondii: epidemiology, feline clinical aspects, and prevention. Trends Parasitol. 2010; 26(4):190-6. [PubMed: 20202907]

29. Dubey JP, Lindsay DS, Speer CA. Structures of Toxoplasma gondii tachyzoites, bradyzoites, and sporozoites and biology and development of tissue cysts. Clin Microbiol Rev. 1998; 11(2):267-99. [PubMed: 9564564]

30. Khan IA, Ely KH, Kasper LH. A purified parasite antigen (p30) mediates CD8+ T cell immunity against fatal Toxoplasma gondii infection in mice. J Immunol. 1991; 147(10):3501-6. [PubMed: 1940350]

31. Angus CW, Klivington-Evans D, Dubey JP, Kovacs JA. Immunization with a DNA plasmid encoding the SAG1 (P30) protein of Toxoplasma gondii is immunogenic and protective in rodents. J Infect Dis. 2000; 181(1):317-24. [PubMed: 10608781]

32. Bonenfant C, Dimier-Poisson I, Velge-Roussel F, Buzoni-Gatel D, Del Giudice G, Rappuoli R, et al. Intranasal immunization with SAG1 and nontoxic mutant heat-labile enterotoxins protects mice against Toxoplasma gondii. Infect Immun. 2001; 69(3):1605-12. [PubMed: 11179334]

33. Scorza T, D’Souza S, Laloup M, Dewit J, De Braekeleer J, Verschueren H, et al. A GRA1 DNA vaccine primes cytolytic $\mathrm{CD}^{+} \mathrm{T}$ cells to control acute Toxoplasma gondii infection. Infect Immun. 2003; 71(1):309-16. [PubMed: 12496180]

34. Martin V, Supanitsky A, Echeverria PC, Litwin S, Tanos T, De Roodt AR, et al. Recombinant GRA4 or ROP2 protein combined with alum or the gra4 gene provides partial protection in chronic murine models of toxoplasmosis. Clin Diagn Lab Immunol. 2004; 11(4):704-10. [PubMed: 15242945]

35. Mevelec MN, Bout D, Desolme B, Marchand H, Magne R, Bruneel O, et al. Evaluation of protective effect of DNA vaccination with genes encoding antigens GRA4 and SAG1 associated with GM-CSF plasmid, against acute, chronical and congenital toxoplasmosis in mice. Vaccine. 2005; 23(36):4489-99. [PubMed: 15935521]

36. Jongert E, Verhelst D, Abady M, Petersen E, Gargano N. Protective Th1 immune responses against chronic toxoplasmosis induced by a protein-protein vaccine combination but not by its DNAprotein counterpart. Vaccine. 2008; 26(41):5289-95. [PubMed: 18675872]

37. Liu S, Shi L, Cheng YB, Fan GX, Ren HX, Yuan YK. Evaluation of protective effect of multiepitope DNA vaccine encoding six antigen segments of Toxoplasma gondii in mice. Parasitol Res. 2009; 105(1):267-74. [PubMed: 19288132]

38. McLeod R, Skamene E, Brown CR, Eisenhauer PB, Mack DG. Genetic regulation of early survival and cyst number after peroral Toxoplasma gondii infection of $\mathrm{A} \times \mathrm{B} / \mathrm{B} \times \mathrm{A}$ recombinant inbred and B10 congenic mice. J Immunol. 1989; 143(9):3031-4. [PubMed: 2809214]

39. Suzuki Y, Joh K, Orellana MA, Conley FK, Remington JS. A gene(s) within the H-2D region determines the development of toxoplasmic encephalitis in mice. Immunology. 1991; 74(4):732-9. [PubMed: 1783431]

40. Mack DG, Johnson JJ, Roberts F, Roberts CW, Estes RG, David C, et al. HLA-class II genes modify outcome of Toxoplasma gondii infection. Int J Parasitol. 1999; 29(9):1351-8. [PubMed: 10579423]

41. Brown CR, David CS, Khare SJ, McLeod R. Effects of human class I transgenes on Toxoplasma gondii cyst formation. J Immunol. 1994; 152(9):4537-41. [PubMed: 8157968]

42. Brown CR, McLeod R. Class I MHC genes and CD8+ T cells determine cyst number in Toxoplasma gondii infection. J Immunol. 1990; 145(10):3438-41. [PubMed: 2121825]

43. Gazzinelli R, Xu Y, Hieny S, Cheever A, Sher A. Simultaneous depletion of CD4 ${ }^{+}$and CD8 ${ }^{+} \mathrm{T}$ lymphocytes is required to reactivate chronic infection with Toxoplasma gondii. J Immunol. 1992; 149(1):175-80. [PubMed: 1351500] 
44. Blanchard N, Gonzalez F, Schaeffer M, Joncker NT, Cheng T, Shastri AJ, et al. Immunodominant, protective response to the parasite Toxoplasma gondii requires antigen processing in the endoplasmic reticulum. Nat Immunol. 2008; 9(8):937-44. [PubMed: 18587399]

45. Frickel EM, Sahoo N, Hopp J, Gubbels MJ, Craver MP, Knoll LJ, et al. Parasite stage-specific recognition of endogenous Toxoplasma gondii-derived CD8+ T cell epitopes. J Infect Dis. 2008; 198(11):1625-33. [PubMed: 18922097]

46. Yang Y, Xiang Z, Ertl HC, Wilson JM. Upregulation of class I major histocompatibility complex antigens by interferon gamma is necessary for T-cell-mediated elimination of recombinant adenovirus-infected hepatocytes in vivo. Proc Natl Acad Sci U S A. 1995; 92(16):7257-61. [PubMed: 7638177]

47. Gazzinelli RT, Wysocka M, Hayashi S, Denkers EY, Hieny S, Caspar P, et al. Parasite-induced IL-12 stimulates early IFN- $\gamma$ synthesis and resistance during acute infection with Toxoplasma gondii. J Immunol. 1994; 153(6):2533-43. [PubMed: 7915739]

48. Hunter CA, Subauste CS, Van Cleave VH, Remington JS. Production of gamma interferon by natural killer cells from Toxoplasma gondii-infected SCID mice: regulation by interleukin-10, interleukin-12, and tumor necrosis factor alpha. Infect Immun. 1994; 62(7):2818-24. [PubMed: 7911785]

49. Denkers EY, Gazzinelli RT. Regulation and function of T-cell-mediated immunity during Toxoplasma gondii infection. Clin Microbiol Rev. 1998; 11(4):569-88. [PubMed: 9767056]

50. Lunde MN, Jacobs L. Antigenic differences between endozoites and cystozoites of Toxoplasma gondii. J Parasitol. 1983; 69(5):806-8. [PubMed: 6200590]

51. Sabin AB. Toxoplasmic encephalithes in children. J Am Med Assoc. 1941; 116:801-7.

52. Giraldo M, Cannizzaro H, Ferguson MA, Almeida IC, Gazzinelli RT. Fractionation of membrane components from tachyzoite forms of Toxoplasma gondii: differential recognition by immunoglobulin $\mathrm{M}(\mathrm{IgM})$ and $\mathrm{IgG}$ present in sera from patients with acute or chronic toxoplasmosis. J Clin Microbiol. 2000; 38(4):1453-60. [PubMed: 10747125]

53. Khan IA, Green WR, Kasper LH, Green KA, Schwartzman JD. Immune CD ${ }^{+} \mathrm{T}$ cells prevent reactivation of Toxoplasma gondii infection in the immunocompromised host. Infect Immun. 1999; 67(11):5869-76. [PubMed: 10531242]

54. Suzuki Y, Wang X, Jortner BS, Payne L, Ni Y, Michie SA, et al. Removal of Toxoplasma gondii cysts from the brain by perforin-mediated activity of CD8+ T cells. Am J Pathol. 2010; 176(4): 1607-13. [PubMed: 20167872]

55. Wilson DC, Grotenbreg GM, Liu K, Zhao Y, Frickel EM, Gubbels MJ, et al. Differential regulation of effector- and central-memory responses to Toxoplasma gondii Infection by IL-12 revealed by tracking of Tgd057-specific CD8+ T cells. PLoS Pathog. 2010; 6(3):e1000815. [PubMed: 20333242]

56. Takeuchi O, Akira S. Pattern recognition receptors and inflammation. Cell. 2010; 140(6):805-20. [PubMed: 20303872]

57. Bhadra R, Guan H, Khan IA. Absence of both IL-7 and IL-15 severely impairs the development of CD8 T cell response against Toxoplasma gondii. PLoS One. 2010; 5(5):e10842. [PubMed: 20520779]

58. Gabaglia CR, Sercarz EE, Diaz-De-Durana Y, Hitt M, Graham FL, Gauldie J, et al. Life-long systemic protection in mice vaccinated with L. major and adenovirus IL-12 vector requires active infection, macrophages and intact lymph nodes. Vaccine. 2004; 23(2):247-57. [PubMed: 15531044]

59. Molinier-Frenkel V, Lengagne R, Gaden F, Hong SS, Choppin J, Gahery-Segard H, et al. Adenovirus hexon protein is a potent adjuvant for activation of a cellular immune response. $\mathrm{J}$ Virol. 2002; 76(1):127-35. [PubMed: 11739678]

60. Muruve DA. The innate immune response to adenovirus vectors. Hum Gene Ther. 2004; 15(12): 1157-66. [PubMed: 15684693]

61. Suzuki Y, Remington JS. Dual regulation of resistance against Toxoplasma gondii infection by Lyt- $2^{+}$and Lyt- ${ }^{+}$, L3T4 $^{+}$T cells in mice. J Immunol. 1988; 140(11):3943-6. [PubMed: 3259601] 
62. Guiton R, Zagani R, Dimier-Poisson I. Major role for CD8 T cells in the protection against Toxoplasma gondii following dendritic cell vaccination. Parasite Immunol. 2009; 31(10):631-40. [PubMed: 19751475]

63. Parker SJ, Roberts CW, Alexander J. CD8+ T cells are the major lymphocyte subpopulation involved in the protective immune response to Toxoplasma gondii in mice. Clin Exp Immunol. 1991; 84(2):207-12. [PubMed: 1902762]

64. Mason NJ, Liou HC, Hunter CA. T cell-intrinsic expression of c-Rel regulates Th1 cell responses essential for resistance to Toxoplasma gondii. J Immunol. 2004; 172(6):3704-11. [PubMed: 15004174]

65. Sukhumavasi W, Egan CE, Warren AL, Taylor GA, Fox BA, Bzik DJ, et al. TLR adaptor MyD88 is essential for pathogen control during oral toxoplasma gondii infection but not adaptive immunity induced by a vaccine strain of the parasite. J Immunol. 2008; 181(5):3464-73. [PubMed: 18714019]

66. Ko HJ, Yang JY, Shim DH, Yang H, Park SM, Curtiss R 3rd, et al. Innate immunity mediated by MyD88 signal is not essential for induction of lipopolysaccharide-specific B cell responses but is indispensable for protection against Salmonella enterica serovar Typhimurium infection. J Immunol. 2009; 182(4):2305-12. [PubMed: 19201885]

67. Park SM, Ko HJ, Shim DH, Yang JY, Park YH, Curtiss R 3rd, et al. MyD88 signaling is not essential for induction of antigen-specific $\mathrm{B}$ cell responses but is indispensable for protection against Streptococcus pneumoniae infection following oral vaccination with attenuated Salmonella expressing PspA antigen. J Immunol. 2008; 181(9):6447-55. [PubMed: 18941235]

68. Krummen M, Balkow S, Shen L, Heinz S, Loquai C, Probst HC, et al. Release of IL-12 by dendritic cells activated by TLR ligation is dependent on MyD88 signaling, whereas TRIF signaling is indispensable for TLR synergy. J Leukoc Biol. 2010; 88(1):189-99. [PubMed: 20360404] 


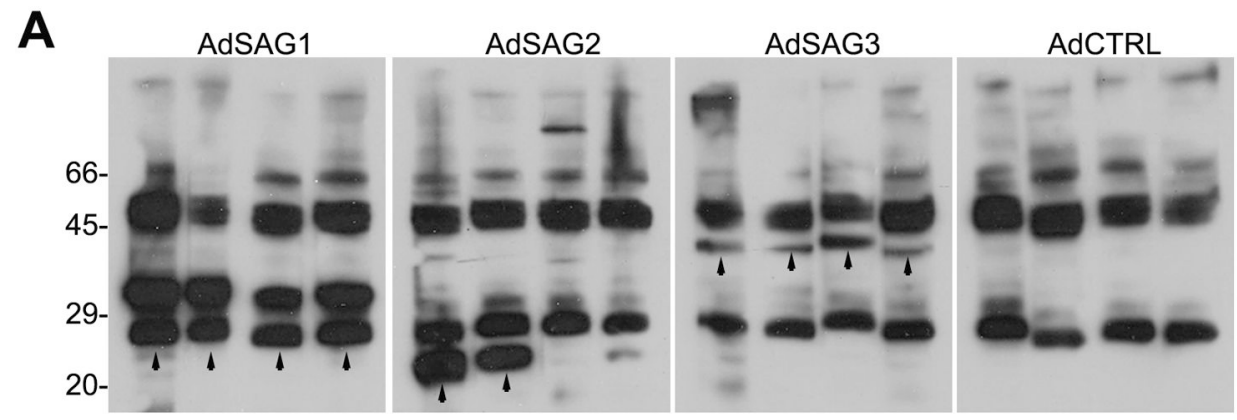

B
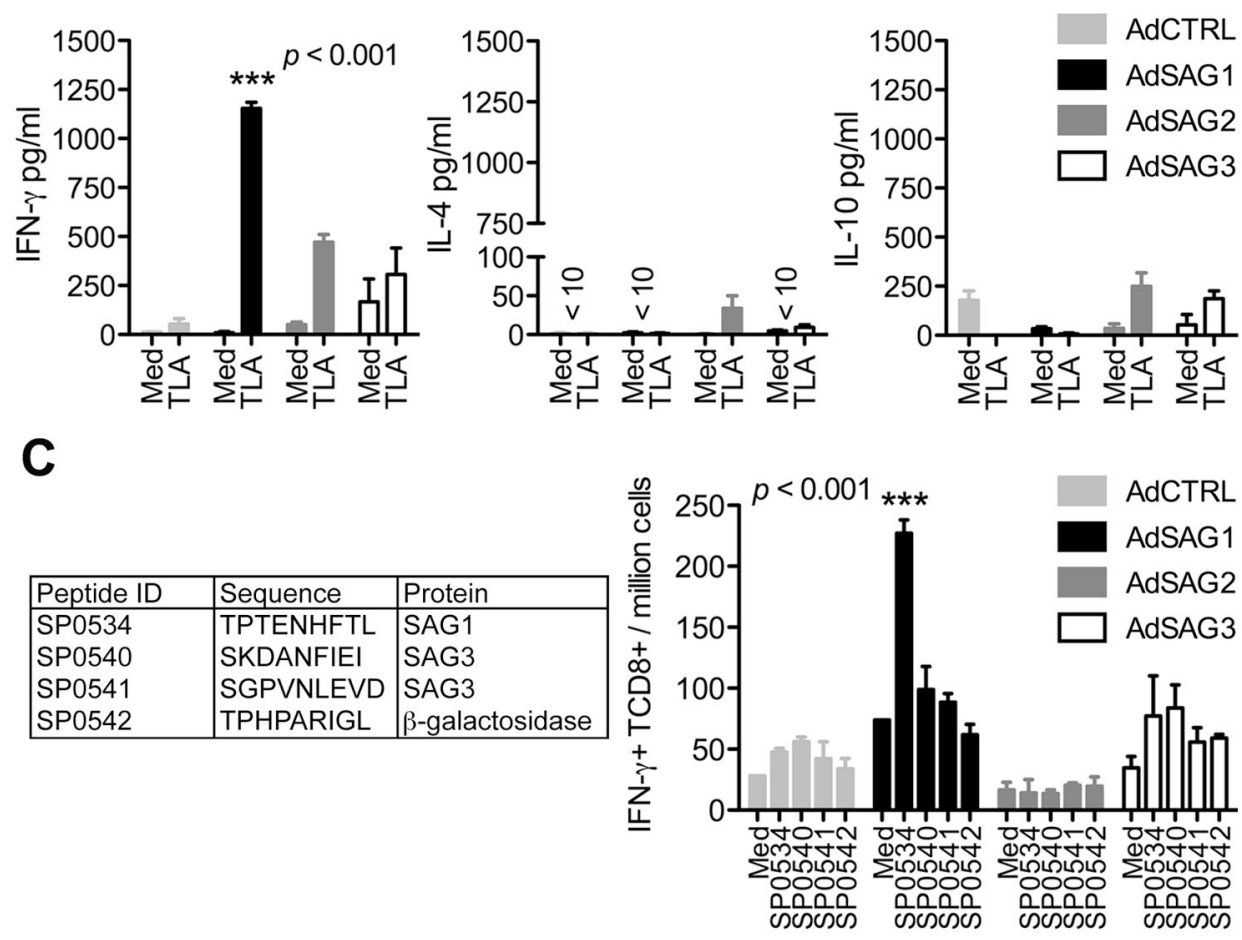

Figure 1. Humoral and cellular immune response after vaccination with adenoviruses: immunogenicity and identification of a SAG1 epitope specific for $\mathrm{CD8}^{+} \mathrm{T}$ lymphocytes C57BL/6 mice received two subcutaneous doses (10 9 PFU) of AdSAG1, AdSAG2, AdSAG3 or AdCTRL, six weeks apart. A, serum samples obtained from four animals, two weeks after boost, were tested individually in Western-blot assay employing tachyzoite total lysate antigen (TLA). Arrowheads indicate the proteins SAG1 (30 kDa), SAG2 (22 kDa) or SAG3 (43 kDa). B, spleen cells were isolated from three animals in each group, two weeks after the second dose, and stimulated in vitro with tachyzoite lysate antigen (TLA) or cultured in plain medium, as control (Med). Cytokines were measured in cell-free supernatants from spleen cultures in ELISA assays. C (left panel), different MHC Irestricted $\left(\mathrm{H} 2-\mathrm{D}^{\mathrm{b}}\right.$ and $\mathrm{H} 2-\mathrm{L}^{\mathrm{b}}$ ) epitopes were mapped in SAG1 and SAG3 proteins. $\mathrm{C}$ (right panel), ELISPOT was performed with spleen cells obtained from 3 animals in each experimental group, two weeks after the second viral dose, and stimulated in vitro with synthetic peptides corresponding to MHC I-restricted epitopes listed in the left panel. Asterisks (*) indicate that difference is statistically significant when comparing to the counterpart vaccination groups or different stimuli used in vitro. The results are representative of one out of two experiments that yield similar results. 

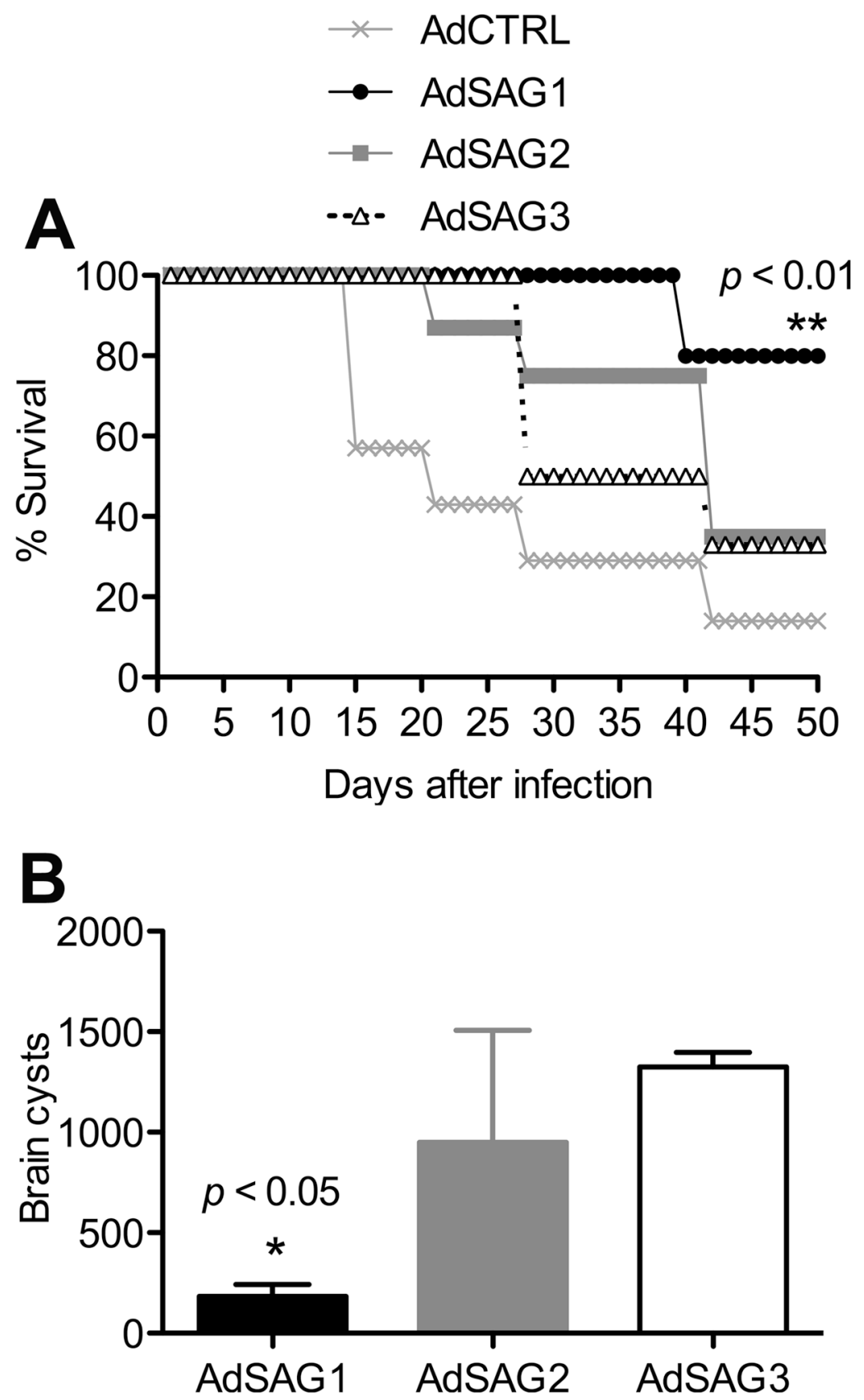

Figure 2. Vaccination with rAd5 expressing SAG1 protects the highly susceptible C57BL/6 mice from challenge with $T$. gondii

Groups of 10 C57BL/6 mice received two subcutaneous doses ( $10^{9}$ PFU) of AdSAG1, AdSAG2, AdSAG3 or AdCTRL, six weeks apart. Two weeks after the boost, mice were orally challenged with the ME49 strain of T. gondii. A, survival of animals was followed for 50 days after challenge. Statistical analysis of mortality curves shows a significant difference between AdSAG1 and all other groups. B, the number of cysts in the brain was evaluated in survivors at day 50 after the challenge. Asterisks $(*)$ indicate that differences are statistically significant when comparing to the counterpart vaccination groups. The results are representative of one out of two experiments that yield similar results. 

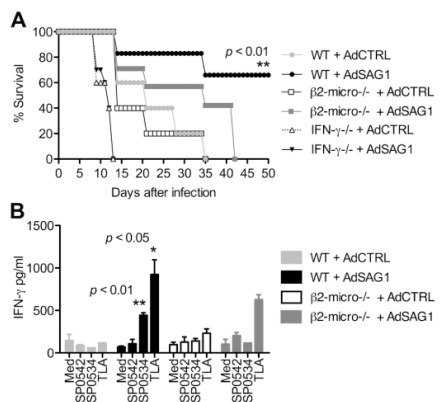

Figure 3. IFN- $\gamma$ and $\mathrm{CD8}^{+} \mathrm{T}$ cells are important mediators of protection elicited by vaccination with AdSAG1

Mice deficient in IFN- $\gamma\left(\mathrm{IFN}-\gamma^{-/-}\right)$or $\mathrm{CD}^{+}$T cells $\left(\beta 2-\right.$ micro $\left.^{-/-}\right)$, and wild type (WT) C57BL/6 counterparts were vaccinated with two doses of AdSAG1 or AdCTRL, six weeks apart. A, two weeks after boost, animals (6 per group) were challenged orally with the ME49 strain. Survival was followed for 50 days after challenge. At day 14 after challenge, all IFN- $\gamma^{-/-}$mice succumbed to infection, irrespective of the rAd5 received. At later time points of infection (from 35 to 50 days), the survival of AdSAG1-vaccinated WT mice was significantly higher than that of any $\beta 2-$ micro $^{-/-}$group. B, spleen cells were obtained from 3 animals from each group, two weeks after the last dose of rAd5, and cultured in vitro without antigens (Med) or in presence of MHC I-restricted epitopes (SP0534 from SAG1; SP0542 from $\beta$-galactosidase) or TLA. The levels of IFN- $\gamma$ in the supernatant of spleen cultures were measured in ELISA assays. Asterisks (*) indicate that difference is statistically significant when compared to the counterpart vaccination groups or different stimuli used in vitro. The experiments were performed two times, yielding similar results. 

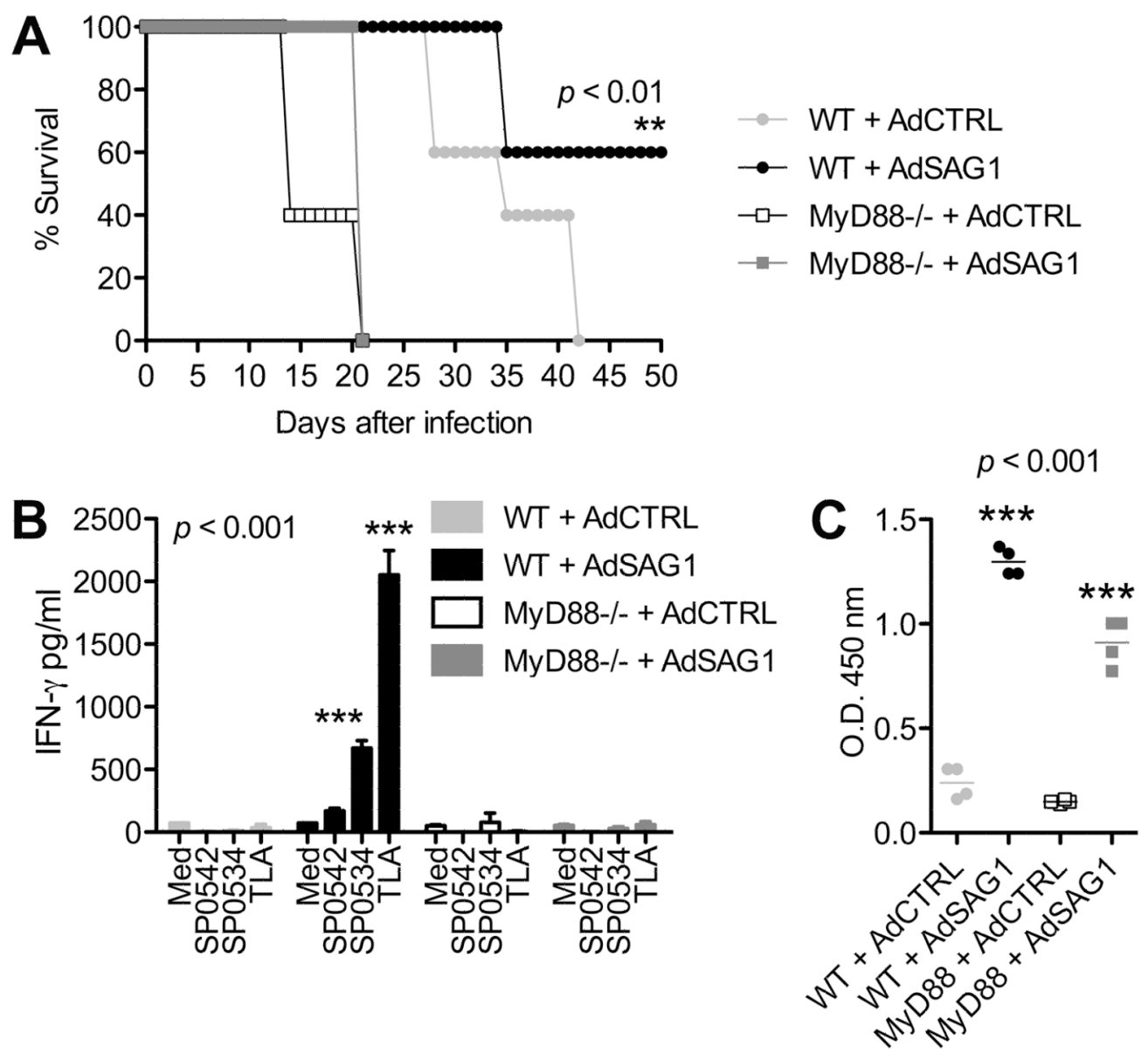

Figure 4. The protection induced by vaccination with AdSAG1 is dependent on MyD88 Mice deficient in MyD88 (MyD88 $8^{-1}$ ), and wild type (WT) C57BL/6 were vaccinated with two doses of AdSAG1 or AdCTRL, six weeks apart. A, two weeks after boost, animals (6 per group) were challenged with an oral dose of ME49 strain. Survival was followed for 50 days after challenge. Statistical analysis indicates that survival of AdSAG1-vaccinated WT mice is significantly higher than the $\mathrm{MyD} 88^{-/-}$mice. $\mathrm{B}$, spleen cells were obtained from 3 vaccinated animals from each group, two weeks after the last dose of rAd5, and cultured without stimulation (Med) or in the presence of MHC I-restricted peptides (SP0534; SP0542) or TLA. The levels of IFN- $\gamma$ in the supernatant of spleen cultures were measured by ELISA. C, serum samples (4 animals) were tested in ELISA with TLA, for presence of anti-SAG1 antibodies. Positive results confirm that in vivo immunization was successful in all mice that received AdSAG1. Asterisks (*) indicate that difference is statistically significant when comparing the counterpart vaccination groups or different stimuli used in vitro. The results are representative of one out of two experiments that yield similar results. 

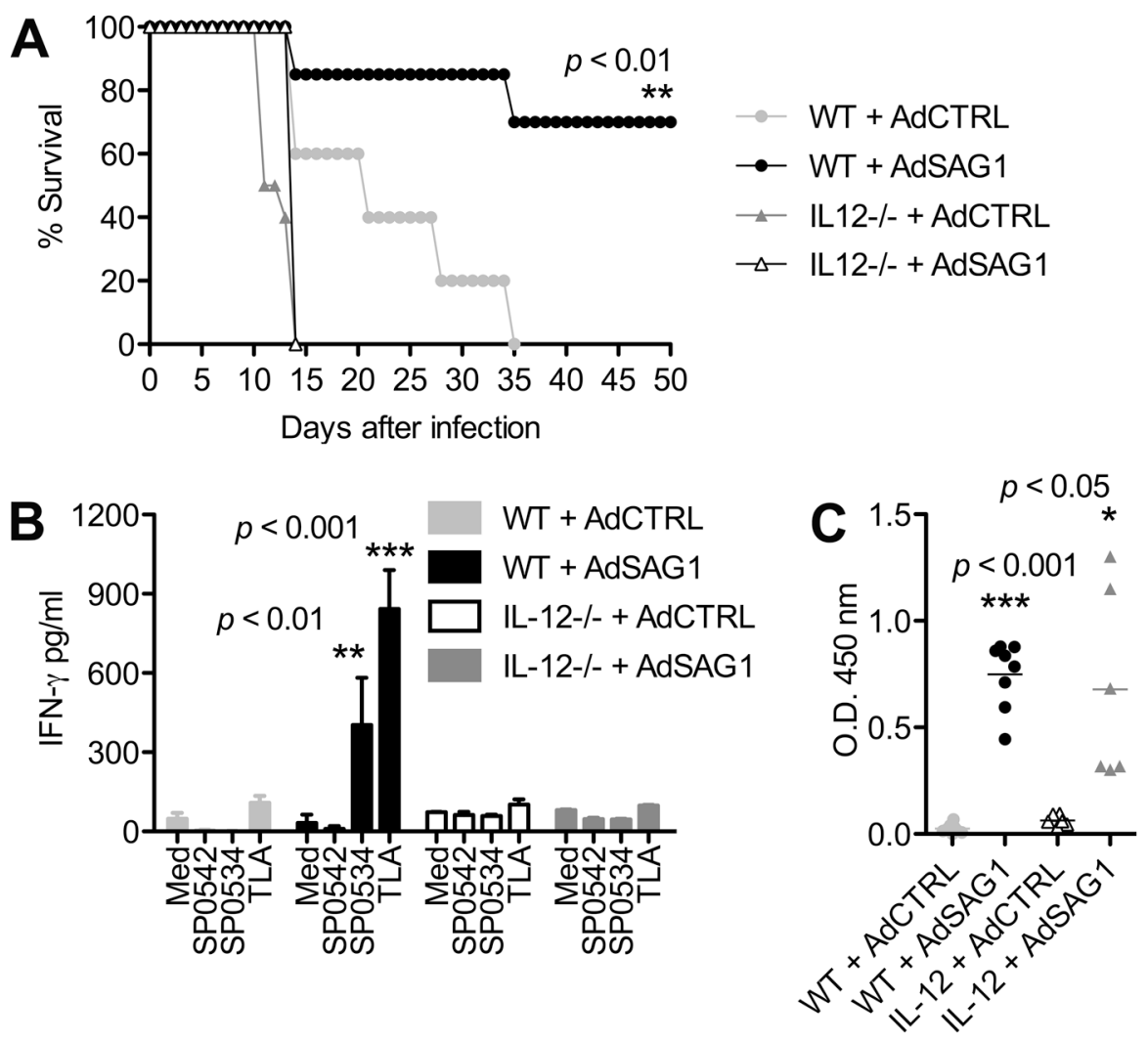

Figure 5. The protection induced by vaccination with AdSAG1 is dependent on endogenous IL-12

Mice deficient in IL-12 (IL-12 $2^{-/-}$), and wild type (WT) C57BL/6 counterparts were vaccinated with two doses of AdSAG1 or AdCTRL, six weeks apart. A, two weeks after boost, animals (6-8 per group) were challenged with an oral dose of ME49 strain. Survival was followed for 50 days after challenge. Statistical analysis confirms that survival of AdSAG1-vaccinated WT mice is significantly higher than that of IL-12-/- mice. B, spleen cells were obtained from 3 vaccinated animals from each group, two weeks after the last dose of rAd5, and cultured in absence of simulation (Med) or with MHC I-restricted epitopes (SP0534; SP0542) or TLA. The levels of IFN- $\gamma$ in the supernatant of spleen cultures were measured by ELISA. C, serum samples (6-8 animals) were tested in ELISA with TLA, for presence of anti-SAG1 antibodies. Positive results confirm that in vivo immunization was successful in all mice that received AdSAG1. Asterisks (*) indicate that difference is statistically significant when comparing the counterpart vaccination groups or different stimuli used in vitro. The presented results are representative of one out of two experiments that yield similar results. 